\title{
Introduction: The midway point of the UN Decade of Education for Sustainable Development: current research and practice in ESD
}

\author{
Gerhard de Haan • Inka Bormann • Alexander Leicht
}

Published online: 9 June 2010

(C) Springer Science+Business Media B.V. 2010

"Education for sustainable development is setting a new direction for education and learning for all. It promotes quality education, and is inclusive of all people. It is based on values, principles and practices necessary to respond effectively to current and future challenges." This ambitious claim is part of the Bonn Declaration, the final document of the UNESCO World Conference on Education for Sustainable Development, which took place on the occasion of the mid-term of the UN Decade of Education for Sustainable Development (2005-2014) in the spring of 2009 in Bonn, Germany. The conference was organised by UNESCO and the German Federal Ministry of Education and Research, in cooperation with the German Commission for UNESCO. It was attended by 900 participants from around 150 countries, among them almost 50 ministers and vice-ministers. Against this background, the aim of this issue of the International Review of Education is to provide a platform for an analysis of the increasingly prominent field of Education for Sustainable Development (ESD). In particular, the concern of the issue is threefold: (i) to introduce and critically discuss the concept of ESD as part of a strategy to cope with unsustainable development patterns with regard to economic growth, environmental degradation and social injustice; (ii) to highlight the wide range of practice in and research on ESD; (iii) to draw out possible parallels and inter-linkages between the field of ESD research and education research more generally.

\footnotetext{
G. de Haan $(\bowtie) \cdot$ I. Bormann

Erziehungswissenschaftliche Zukunftsforschung (Educational Future Studies),

Freie Universität Berlin, Arnimallee 9, 14195 Berlin, Germany

e-mail: sekretariat@institutfutur.de; dehaan@zedat.fu-berlin.de

I. Bormann

e-mail: inka.bormann@fu-berlin.de
}

\section{A. Leicht}

UN Decade of Education for Sustainable Development, German Commission for UNESCO, Langwartweg 72, 53129 Bonn, Germany

e-mail: leicht@esd.unesco.de 
In putting together this issue we have been guided by our persuasion that ESD should be considered relevant for all areas of education and education levels, be it primary education, secondary education, higher, adult or vocational education - and in formal, non-formal or informal learning settings. We are of course aware that other education concepts could claim centre-stage in a similar fashion, and that the potential of ESD cannot merely be asserted but has to be backed up by substantial evidence. Another aim of this issue, therefore, is to invite critical and constructive debate on ESD, its potentials and shortcomings. This introduction provides a first sketch of the concept of ESD; carries out a stock-taking of the implementation of ESD so far; and gives an overview of the articles assembled in this issue.

It might be reasonable to start off with a brief historical sketch. Almost three decades ago, around 180 states signed the closing document Agenda 21 of the United Nations Conference on Environment and Development, or Rio Conference, as it is commonly known. Chapter 36 of Agenda 21 is dedicated to the importance of education in the process of achieving sustainable development. Without a widereaching mental transformation, without awareness-raising, without a substantial global education effort, as is stated here and in fact in many other chapters of this key document for the twenty-first century, sustainable development is simply not achievable.

The international community under the umbrella of the United Nations, in 1992 in Rio de Janeiro and at its follow-up conference in Johannesburg in 2002, was not alone in seeing things this way. In international discourse-political as well as scientific_-it quickly became clear that the concept of sustainable development necessitated a reorientation of both environmental education and development education, the two concepts that can roughly be seen as predecessors of ESD. When one takes a closer look at the transformation of environmental education and development education, or global learning, into ESD, major conceptual shifts can clearly be identified. ESD led away from the 'threat' and 'suffering' scenarios and towards 'modernisation' scenarios. It became a question of learning about creative solutions that could make economic prosperity and the conservation of nature a simultaneous possibility; of providing the knowledge needed to develop innovative, resource-saving techniques; of knowledge of new forms of political action in which the contribution of civil society is more highly valued; of reflecting on new lifestyles which combine well-being, contentment and respect for other people and nature; of taking up the viewpoints of people from other countries; of fair trade initiatives and new forms of worldwide cooperation. ESD thus has the aim of making people capable of acting to create a fairer worldwide distribution of opportunities in life, while respecting environmental considerations. Most importantly, perhaps, ESD does not only look at one aspect of development- the environment, say, or the economy-but always considers the inter-linkages between the various pillars of sustainable development.

Considering the wide-ranging political, societal as well as scientific challenges ESD must deal with, it is an ongoing task to reduce the supposed vagueness and unspecificity of the concept. This issue provides some suggestions how to go about in that regard. 
Current work on ESD, both political and academic, is carried out within the framework of the United Nations Decade of Education for Sustainable Development (DESD) that was declared by the United Nations General Assembly for the years 2005-2014. ${ }^{1}$ Its rationale is straightforward: if the world wants to advance on its path towards sustainable development, much more emphasis than before needs to be placed on ESD. Sustainable development requires a fundamental change of mind of every individual citizen; small adjustments will not do. "The overall goal of the DESD", according to the basic strategic document drafted by UNESCO, the lead agency for the implementation of the DESD, "is to integrate the principles, values, and practices of sustainable development into all aspects of education and learning." 2 This goal is being pursued by a large number of stakeholders at various levels: UN organisations and programmes, national governments, international and national NGOs, and individual activists all work towards making sustainable development a key element of education. ${ }^{3}$

Without doubt, the Decade has so far managed to raise awareness of the importance of ESD to the international education agenda. This has been very visible, for example, at the sessions of the UNESCO General Conference and the UNESCO Executive Board since 2005, where from being a relatively minor agenda item, ESD has become increasingly prominent and has been given an ever-more important place in the UNESCO programme. Furthermore, nationally and internationally, the Decade has provided an umbrella, giving coherence to the many different education agendas related to sustainable development-development education, environmental education, consumer education, and so on-and thus increased their political leverage; ESD is now often acknowledged as an important aspect - and in part as a driving force - of educational reform efforts. While it is clear that national and cultural specificities and variations of implementing ESD are considerable, most stakeholders have also resisted the easy relativism of accepting anything as ESD that anyone chooses to label ESD (a relativism that would be ultimately self-defeating, as always with relativism). Most stakeholders subscribe to the view that ESD needs to integrate the three dimensions of sustainable development-environmental, economic, social or socio-cultural-and needs to have a participatory component. In addition, of course, the Decade has led to numerous concrete projects on the ground.

A first evaluation of activities undertaken within the framework of the DESD was undertaken by UNESCO in 2009 with a focus on the contexts in which ESD is conducted and the structures with which the DESD is driven forward. The report found, among other things, that a considerable number of countries have committed themselves to integrating ESD into formal education, that there is a remarkable presence of ESD in national policy documents, and that many countries have put in place national coordinating bodies for the DESD. Challenges include the regional unevenness of ESD implementation, awareness of ESD in the wider educational

\footnotetext{
1 United Nations (2002).

2 UNESCO (2005, p. 6).

3 See, for example, UNESCO, UNECE (2007).
} 
community and in the general public, the reorientation of curricula, and the availability of sufficient budgetary provisions for ESD measures. ${ }^{4}$

A clear testimony to the growing momentum of ESD was provided by the Spring 2009 UNESCO World Conference on ESD in Bonn, Germany. The objectives of the conference were to highlight the essential contribution of ESD to quality education; to promote international exchange on ESD; to carry out a stock-taking of ESD implementation; and to develop strategies for the way ahead in the DESD. The 3day deliberations led to the substantial Bonn Declaration, which was subsequently unanimously endorsed by Member States at the UNESCO General Conference in October 2009. The Declaration forcefully articulates the potential of ESD for achieving sustainable development and lists specific strategic guidelines for the implementation of the DESD in its second half. ${ }^{5}$

On the basis of the conference and its final declaration, we believe that the following aspects in particular will be central to the promotion of ESD in the coming years. First, ESD needs to be recognised not as yet another addition to the education agenda or the curriculum. Because the competencies it allows students to acquire are equally central to shaping a future in human dignity and to developing a full and autonomous personality, ESD should be acknowledged as a mark of quality in education. We strongly believe that ESD makes teaching and learning more meaningful, makes what is learned more relevant, increases the motivation of learners, and raises overall performance results. ESD, thus, is a decisive element of quality education. With regard to the international education agenda, the contribution of ESD to quality also provides an excellent link to the efforts of the Education for All (EFA) agenda.

Second, with regard to the means of implementation, we believe that so far the DESD has been successful where it has combined political support with civilsociety activity. ${ }^{6}$ That sustainable development is a multi-stakeholder endeavour and can only be achieved through a combination of top-down and bottom-up strategies has long been established. This is equally true for ESD. Of course, calling a particular project a multi-stakeholder initiative always carries the danger of an evasion of accountability, as it were; if many stakeholders are involved, it might be "not me" but "the other" who should be in charge of a particular activity. Yet it is important to see that with regard to ESD, having multiple stakeholders means that each player has their specific share of responsibility: governments to provide political support, frameworks, and funding; and civil-society initiatives to play a big role in the concrete implementation on the ground, in identifying innovative projects and, not least, to mobilise public support and pressure for responsible policies. An increasingly important player in the coming years, and for obvious reasons, will be the private sector. It will be important to remind companies and businesses of their

\footnotetext{
${ }^{4}$ UNESCO (2009).

5 UNESCO, BMBF, German Commission for UNESCO (2009).

${ }^{6}$ Implementing the DESD as a partnership project of politics and civil society has been an important characteristic of the German DESD activities. See, for example, German Commission for UNESCO (2009).
} 
responsibility, and to demonstrate to them how they can benefit from including ESD into their work.

A further important element of the multi-stakeholder nature of the DESD is that effective implementation depends on a dialogue between theoretical concepts and scientific advances on the one hand, and practical work in projects and politics on the other-a dialogue to which we want to contribute with this issue.

\section{Contents of the special issue}

The issue is divided into two sections - thematic and good practice. The selection of contributions aims to provide an insight into the inter- and trans-disciplinary discourse on ESD. The articles presented here cover a wide range of understandings concerning the core of ESD, its theoretical and political backgrounds as well as the theoretical and political challenges it faces. They also cover a broad spectrum with regard to the social functions and expected impacts of ESD as well as practical suggestions on how to enhance, facilitate or support ESD practices. Given that there are diverse conceptualisations of ESD, the articles, of course, also discuss possible counter-arguments to this new education concept.

The thematic articles aim to provide insights into the current state of ESD research and practice, as well as potential or effective contributions from ESD research to other dominant discourses in education: from the issue of school retention and lifelong learning via Education for All through to the economic dimension of education or the implementation work of international actors. The case study articles detail endeavours to put the normative concept of ESD into practice. These range from efforts to implement the sustainable development agenda into study programmes, through heuristic concepts for the orientation and assessment of learning outcomes of students, to efforts to increase public awareness for sustainable development. Articles come from all world regions and, especially in the casestudies section, also mirror different regional priorities, academic traditions, and political agendas. As guest editors, we feel that this breadth can be regarded as a strength of the selection.

The thematic focus of the selected articles can be considered representative of the highly differentiated research in education in general. One could say that nowadays a large part of empirical education research is concerned with the effects of teaching and learning as well as with modes of effective and efficient regulation within the education system. This is particularly so against the backdrop of education systems under pressure to reduce inequality and exclusion, to grant access to education, to provide evidence of success, and so on-in an era of financial restrictions and increasing claims and needs to perform better qualitatively and quantitatively. How this pressure shows in detail, and the responses to it, differs from region to region as historical, social, environmental and economic conditions and needs vary. In this context, we also see this issue of the International Review of Education as a contribution to tackling the more general education concerns from a specific angle, that of ESD. In that sense, it also aims to provide indications on how ESD research 
is linking up with the subjects and methods of education research in general or, if you will, with the mainstream of education research.

Thematic articles

Within the thematic section, Heila Lotz-Sisitka (South Africa) aims to spell out a specific ESD research agenda and to uncover existing research trajectories. She asks how ESD might relate to issues of retention and Education for All, and how it might contribute to the quality of teaching and learning in general. She shows that the different discourses she examines are based on different rationales which are not necessarily compatible, in contradiction to the claims often made. She argues for a critical analysis of the interrelated discourses to be able to develop a qualitative understanding of ESD in terms of its contribution to change-oriented learning, to equity, justice and sustainability. Moacir Gadotti's paper (Brazil) also addresses the issue of synergy and potential conflict between ESD and Education for All, as ESD implies transformation in many areas of education systems, schools and schooling. He puts forth the argument that ESD as an integrative and dynamic concept provides a contribution to an individual's task of coping with increasing economic and social pressure in ways which do not damage the environment. Manzoor Ahmed (Bangladesh) discusses the economic dimensions of sustainable development-an issue which came to the ESD research agenda fairly late and is widely contested. The starting point of the paper is that poverty is a main source of non-sustainable development patterns and that, in turn, efforts to reduce poverty are direct contributions to sustainable development. Therefore, the author sees ESD as a means to reduce poverty and puts forward the idea that ESD has to address economic competencies as an element of critical literacy and an awareness concerning inequality in order to combat poverty. The paper by Mary Joy Pigozzi (United States of America) deals with achievements, questions and strategies regarding the way forward in implementing the DESD. The author looks at implementation from a global perspective, not without referring to definitional dilemmas that stem from the global-scale task which has, however, to be 'translated' into regionally or locally adapted meanings. ESD is, in her view, fundamentally educative in principle, as it aims to help to develop attitudes, skills and knowledge to make informed and responsible decisions. From her experience with the international implementation of the UN Decade and the review of its implementation, she outlines some issues for further research and development in ESD. Starting from a community-based case study, Liu Yunhua and Alicia Constable (China) argue that ESD as a global task has to be linked with, or rather has to build on, local cultures and indigenous knowledge. While ESD research is often focused on teaching and learning processes in formal education institutions, they confront the issue of how to integrate ESD into informal and non-formal lifelong learning.

Examples of good practice

In the case study section, Sosten S. Chiotha (Malawi) deals with mainstreaming environment and sustainability in African universities. He is calling into question 
whether good-practice examples illustrate a limited notion of sustainable development. The article implicitly argues against the simplistic idea that general concepts can always be easily applied in different contexts. Rami Zurayk, Mutasem el Fadel and Iman Nuwayhid (Lebanon) discuss the implementation of a study programme. They provide an evaluation of the ESD dimension of an inter-faculty graduate environmental sciences programme. They consider the programme as a quite inspiring approach to inform good practice cases. However, they make the point that it should be subject to further adaptation in order to be implementable in higher education institutions. The example of good practice which Gerhard de Haan (Germany) discusses arose from a German state-funded programme to implement ESD in schools. With regard to the fact that education always implies unquantifiable components, the article focuses on competences as learning outcomes. It aims to provide an heuristic device which might inform practical teaching as well as future competence diagnoses. Whereas this article refers to students' formal learning processes, Tiedao Zhang's article (China) approaches the organisational mechanisms used to carry out capacity-building for the implementation of ESD. He makes the point that only networks that include students, teachers, education authorities and local communities are able to 'sustainably' implement ESD. Alejandrina MataSegreda (Costa Rica) introduces a case study in which ESD has become part of the curriculum in the national education system. The Marine Education Programme in Costa Rica is presented as an evaluation of ESD by applying quality criteria for ESD schools, developed by the international ENSI network. She shows that these criteria and guidelines achieve their objective of orienting the alignment and implementation of ESD. Akpezi Ogbuigwe (Nigeria) explains how the United Nations Environment Programme (UNEP) aims to support ESD across the world. By way of example, she highlights ESD innovations in African universities. She makes the point that teaching graduates in ESD is a means for the future enhancement and diffusion of ESD as a policy.

As previously stated, there is no clearly delineated and distinct definition of ESD, and there is not a quasi-uniform method of organising teaching-learning processes. Instead of being unhappy about this situation, one could argue that the diversity of conceptualisations and approaches shows the vibrancy and vitality of ESD theories and practices. We particularly hope that those who had not yet been familiar with ESD or those who had been convinced that ESD is a short episode or a quicklywaning academic fashion will find reasons and occasions to link their own research, or practices, to the challenging and ongoing project of ESD.

We would like to express our sincere gratitude to the authors for contributing an article to this issue, to the anonymous peer reviewers for improving this issue, and to the IRE Editorial Office in Hamburg for its excellent and ever-friendly support.

\section{References}

German Commission for UNESCO. (2009). Learning sustainability: UN decade of education for sustainable development (2005-2014): Stakeholders and projects in Germany. Bonn: German Commission for UNESCO. 
UNESCO. (2005). United Nations decade of education for sustainable development (2005-2014): International implementation scheme. Paris: UNESCO.

UNESCO. (2009). Review of contexts and structures for education for sustainable development 2009. Paris: UNESCO.

UNESCO, German Federal Ministry of Education and Research (BMBF), \& German Commission for UNESCO. (2009). UNESCO world conference on education for sustainable development: Proceedings. Paris/Berlin/Bonn: UNESCO/BMBF/German Commission for UNESCO.

UNESCO, \& UNECE. (2007). United Nations decade of education for sustainable development (20052014): Good practices in the UNECE region. Paris: UNESCO.

United Nations. (2002). Resolution 57/254 adopted by the General Assembly, 20 December 2002

\section{Author Biographies}

Gerhard de Haan is the Professor for Educational Future Studies at the Free University of Berlin, Germany. His extensive research and development projects focus on Education for Sustainable Development, particularly on the modernisation of the school system. His research is also concerned with social constructivism and knowledge societies. He is a member of various journal and research advisory boards, and is the Chair of the German National Committee for the UN Decade of Education for Sustainable Development.

Inka Bormann is Assistant Professor for Education at the Free University of Berlin, Germany. Her recent projects have focused on modernisation and innovations in organisations and the education system as a whole, particularly with regard to governance, the transfer of knowledge and collective learning. Her research is concerned with Education for Sustainable Development and she builds on social constructivist as well as on discourse theories. She is a member of the UNECE Expert Group on Education for Sustainable Development.

Alexander Leicht has been Head of the Secretariat for the UN Decade of Education for Sustainable Development (DESD) at the German Commission for UNESCO since 2004. The DESD is implemented in Germany by the German Commission of UNESCO on the basis of a unanimous resolution of the German Parliament and with support from the Federal Ministry of Education and Research. Before joining the German Commission for UNESCO, Alexander Leicht taught German language, literature and culture at the University of Nottingham, United Kingdom, and at the University of Veszprém, Hungary. $\mathrm{He}$ holds a PhD in American Studies from the University of Nottingham and a degree in German, American Studies and Education from the University of Marburg, Germany. 